\title{
„STO TOMÓW CZASOPISMA «ARCHIWA BIBLIOTEKI I MUZEA KOŚCIELNE»". DZIEJE, DOROBEK I PERSPEKTYWY BADAWCZE CZASOPISM KOŚCIELNYCH". SYMPOZJUM Z OKAZJI WYDANIA 100. TOMU PÓEROCZNIKA „ARCHIWA BIBLIOTEKI I MUZEA KOŚCIELNE”. LUBLIN 9 GRUDNIA 2013
}

W 2013 r. Ośrodek Archiwów Bibliotek i Muzeów Kościelnych świętował wydanie setnego numeru półrocznika Archiwa Biblioteki i Muzea Kościelne. Z tej okazji w dniu 9 grudnia 2013 r. w gmachu Biblioteki Uniwersyteckiej KUL odbyło się sympozjum Sto tomów czasopisma „Archiwa Biblioteki i Muzea Kościelne. Dzieje, dorobek i perspektywy badawcze czasopism kościelnych. Obrady odbywały się w nowej Czytelni Teologiczno-Filozoficznej Biblioteki Uniwersyteckiej KUL.

Sesję otworzył Dziekan Wydziału Teologii KUL, ks. prof. Marek Chmielewski. W swojej krótkiej mowie skupił się na ukazaniu roli kościelnych instytucji w zachowaniu dóbr kultury, które są świadectwem przeszłości nie tylko Kościoła katolickiego. Wspomniał również o różnorodnej działalności KUL w sferze kultury.

Dyrektor Ośrodka Archiwów Bibliotek i Muzeów Kościelnych ks. dr hab. Waldemar W. Żurek, prof. KUL, przedstawił historię i zadania statutowe realizowane przez podległą mu instytucję. Opisał również najważniejsze osiągnięcia Ośrodka ABMK w dokumentacji kościelnych dóbr kultury.

Dyrektor Biblioteki Uniwersyteckiej KUL Barbara Zezula, przedstawiła pokrótce dzieje kierowanej przez siebie książnicy. W swojej wypowiedzi zwróciła uwagę na różnorodne inwestycje w bibliotece, dzięki którym warunki pracy naukowej uległy znacznemu polepszeniu. Dodatkowo przedstawiła najważniejsze cechy Biblioteki Uniwersyteckiej KUL, które odróżniają ja od innych tego typu instytucji w Polsce.

Wykład inaugurujący sesję wygłosił Naczelny Dyrektor Archiwów Państwowych prof. Władysław Stępniak. W swoim referacie Potrzeba refleksji nad dziedzing archiwalna przedstawił najnowsze rozwiązania organizacyjne instytucji 
kultury wprowadzane w Kanadzie i USA. W krajach tych często łączy w jedną instytucję archiwa, biblioteki i muzea. Wspomniał również o intensyfikacji współpracy między archiwami europejskimi po II wojnie światowej.

Prelegent przedstawił również Narodowy Zasób Archiwalny obejmujący dokumentację przechowywaną wieczyście i obejmującą zbiory państwowe oraz prywatne. Ta sytuacja wymusza współpracę między archiwami państwowymi i kościelnymi. Wspomniane zostały również problemy prawne dostępu do archiwów państwowych oraz kościelnych, które obowiązują odrębne przepisy.

W. Stępniak poruszył również zagadnienie „,masowego kwerendzisty”, który wymusza nowe zasady ustępniania zasobu oraz komputerowego opracowania zbiorów powiązane $\mathrm{z}$ wiedzą i umiejętnościami czytelnika. Prelegent przedstawił metody opracowania zbiorów. Aktualnie NDAP powołała trzy zespoły naukowe mające na celu: wypracowanie ogólnych założeń metodycznych opracowania zbiorów archiwalnych; przygotowywanie indeksów do zasobu archiwalnego (pod kątem wyszukiwarki internetowej np. Google); przygotowanie formatu opisu archiwalnego.

Na koniec W. Stępniak wspomniał o problemie informatyzacji archiwów. Obejmuje ono kilka zagadnień m.in. wdrożenie rejestru Narodowego Zespołu Archiwalnego, rozwój centralnego repozytorium cyfrowego, archiwum dokumentów cyfrowych, zintegrowany system Informacji Archiwalnej ZoSIA.

Dyrektor Archiwum Państwowego w Lublinie dr Piotr Dymmel w swoim wystąpieniu Czasopisma archiwów państwowych w Polsce, przedstawił działalność wydawniczą tych instytucji. Prelegent wskazał, że zadania wydawnicze zostały nałożone na archiwa państwowe już 31 lipca 1918 r. przez Radę Regencyjną. Zostało to powtórzone $\mathrm{w}$ kolejnych aktach prawnych: w dekrecie prezydenta $\mathrm{B}$. Bieruta z $1951 \mathrm{r}$. oraz w ustawie archiwalnej z 1983 r. Również aktualnie w ramach uchwalonej strategii archiwów państwowych na lata 2010-2020 mają być rozszerzona ich działalność wydawnicza.

Czasopisma są wydawane przez Naczelną Dyrekcję Archiwów Państwowych (NDAP) oraz archiwa państwowe: centralne (AGAD, AAN) oraz terenowe. NDAP wydaje najstarsze pismo archiwalne „Archeion”, który ukazuje się od 1927 r. Dotychczas wydano 113 tomów. Natomiast od 1957 r. ukazują się „Teki Archiwalne”, które zawierają edycje źródłowe ważniejszych dokumentów archiwalnych. Pierwsze pisma wydawane przez archiwa terenowe pojawiły się w połowie lat 70. XX wieku. Jednak dopiero w latach 90 . XX w. nastąpił wzmożony ruch wydawniczy periodyków. Spowodowane było to nie tylko przemianami społeczno-politycznymi, ale i rozwojem nowych technologii i sposobów finansowania. Aktualnie na 33 archiwa państwowe (3 centralne i 30 regionalne) pisma wydaje 18 archiwów. Ukazuje się 20 czasopism, przy czym 2 archiwa wydają więcej niż 1 periodyk. Większość pism wydawanych jest we współpracy z różnymi instytucjami. Tematyka poruszana na ich łamach koncentruje się na historii, źródłoznawstwie, naukach pomocniczych historii, edycji źródeł, bibliografii, w węższym zakresie zaś archiwistyce (dzieje archiwum, prezentacja zasobu), choć są również nawet artykuły przyrodnicze.

Prelegent zwrócił uwagę na konieczność potrzeby badań nad piśmiennictwem 
archiwalnym, współpracy między redaktorami tych periodyków, zdefiniowanie i poszerzeniu kregu odbiorców oraz publikacji czasopism online.

Redaktor naczelny pisma „Archiwa Biblioteki i Muzea Kościelne” mgr Artur Hamryszczak przedstawił referat: Pótrocznik „Archiwa Biblioteki i Muzea Kościelne". Przeszłośc-teraźniejszość-przyszłość. Prelegent przybliżył historię powstania w 1956 r. Ośrodka Archiwów Bibliotek i Muzeów Kościelnych oraz jego zadań statutowych. Opisał również początki pisma, założonego przez o. Romualda Gustawa, dyrektora Biblioteki Uniwersyteckiej KUL oraz ks. Stanisława Librowskiego, dyrektora Archiwum Diecezjalnego we Włocławku. A. Hamryszczak przedstawił również artykuły drukowane na łamach ABMK: rozprawy i studia przedstawiające metody pracy stosowane $\mathrm{w}$ archiwistyce, bibliotekarstwie oraz muzealnictwie; teksty o historii zbiorów kościelnych, inwentarze archiwalne i katalogi biblioteczne kościelnych bibliotek i archiwów, teksty źródłowe do historii Kościoła katolickiego na ziemiach polskich (wizytacje, księgi brackie, statuty kapituł, fundacje i erekcje instytucji kościelnych). Przedstawił również sylwetki poszczególnych redaktorów ABMK podkreślając ich działalność naukową. Na koniec opisał najważniejsze wyzwania stojące przed półrocznikiem.

Ks. biskup dr hab. Mariusz Leszczyński przedstawił wykład Biuletyn Muzeum Diecezjalnego w Zamościu. Prelegent opisał dzieje periodyku, którego pierwszy numer ukazał się w $1997 \mathrm{r}$. Redaktorem naczelnym był dyrektor muzeum diecezjalnego ks. dr Mariusz Leszczyński (aktualnie biskup pomocniczy zamojskolubaczowski). Pismo było organem wydawniczym Muzeum Diecezjalnego w Zamościu, redagowanym we współpracy z Muzeum Kresów w Lubaczowie. Autor przedstawił komitet redakcyjny, założenia programowe oraz omówił zawartość poszczególnych tomów. Po ukazaniu się czterech numerów pisma, jego wydawanie zawieszono w 2002 r. Pewną kontynuacją periodyku był wydrukowany jednorazowo w 2005 r. „Biuletyn Kościelnych Dóbr Kultury”.

Następny referat „Archiva Ecclesiae” - organ Międzynarodowego Stowarzyszenia Archiwistów Kościelnych przedstawił ks. dr Stanisław Zimniak SDB, Sekretarz ACCSA (Stowarzyszenie Historyków Salezjańskich) z Rzymu. Prelegent skrótowo opisał historię powstania w 1956 r. w Rzymie Międzynarodowego Stowarzyszenia Archiwistów Kościelnych. Omówił również cele statutowe nowej organizacji. Przedstawił również „Archiva Ecclesiae”, pismo stowarzyszenia, realizujące jego statutowe założenia. Nie jest jednak periodykiem w sensie ścisłym, a raczej pewnego rodzaju serią publikującą materiały z odbywających się sympozjów organizowanych przez Międzynarodowe Stowarzyszenie Archiwistów Kościelnych. Oprócz tego na łamach „Archiva Ecclesiae” opublikowano przewodniki po kościelnych archiwach diecezjalnych i kapitulnych we Włoszech. Prelegent przedstawił również tematykę nie tylko kolejnych numerów pisma ale i kolejnych zjazdów archiwistów kościelnych we Włoszech.

Ks. prof. Marek Inglot SI, Dziekan Wydziału Historii Kościoła Papieskiego Uniwersytetu Gregoriańskiego w Rzymie, zaprezentował wykład „Informationes” organ Papieskiego Instytutu Studiów Kościelnych. Autor przedstawił powstanie w 1958 r. w Rzymie z inicjatywy Stefana Kardynała Wyszyńskiego oraz jezuitów prowincji wielkopolsko-mazowieckiej, wspomnianej instytucji. Jest to 
polski ośrodek naukowo-badawczy o charakterze dokumentacyjno-informacyjnym, zwłaszcza w zakresie dokumentacji archiwalnej Stolicy Apostolskiej, dotyczącej dziejów Kościoła i spraw polskich. Założycielem i pierwszym kierownikiem Instytutu był ks. Eugeniusz Reczek SI (1916-1971), pierwszy dyrektor Ośrodka ABMK. Celem ośrodka są poszukiwania, rejestracja, gromadzenie w formie reprodukcji i udostępnianie materiałów dotyczących historii Kościoła w Polsce, przechowywanych w zbiorach Stolicy Apostolskiej oraz innych zbiorach kościelnych, państwowych i prywatnych, zwłaszcza na terenie Włoch. W roku 1976 został utworzony w Warszawie Punkt Konsultacyjny Instytutu w Rzymie. W związku z tym zaczął być wydawany periodyk naukowy „Informationes". Prelegent przedstawił założenia programowe pisma, skład redakcji oraz pokrótce omówił zawartość każdego numeru.

Bogumiła Warząchowska z Biblioteki Teologicznej Uniwersytetu Śląskiego w Katowicach przedstawiła referat FIDES. Biuletyn Bibliotek Kościelnych. Dokumentacja, informacja, edukacja. Prelegentka zaprezentowała półrocznik FIDES, który jest organem Federacji Bibliotek Kościelnych FIDES. Pierwszy numer ukazał się w 1995 r. Autorka przedstawiła założenia programowe pisma oraz skład redakcji pisma na przestrzeni lat. Podkreśliła rosnący systematycznie poziom merytoryczny pisma, który przejawia się m.in. w zwiększającym się nakładzie czy też powołaniem rady naukowej półrocznika. Pismo jest także periodykiem recenzowanym. Na jego łamach publikują nie tylko pracownicy bibliotek teologicznych uczelni wyższych, seminaryjnych, parafialnych ale także bibliotek uczelni świeckich. B. Warząchowska omówiła również pokrótce zawartość tematyczną półrocznika, wskazując na najbardziej charakterystyczne publikacje.

Następnym prelegentem był ks. mgr Roman Dworacki, dyrektor Archiwum Archidiecezjalnego w Poznaniu, który zaprezentował wystąpienie „Archiwariusz" - biuletyn Archiwum Archidiecezjalnego w Poznaniu. Prelegent omówił historię powstałego w 1925 r. archiwum diecezjalnego w Poznaniu, które jest najstarszą instytucją tego typu w Polsce. W 2005 r. kiedy archiwum świętowało 80. rocznicę powstania zostało powołane pismo „Archiwariusz” jako organ wydawniczy archiwum. W założeniach jest to rocznik. Prelegent przedstawił zawartość pisma. Na łamach pisma publikowane są źródła, opracowania i sprawozdania z działalności AAP w Poznaniu oraz artykuły z innych ośrodków. Popularyzowane są nowe techniki archiwalne i ich wykorzystanie. Przypominane są również sylwetki zasłużonych historyków-archiwistów. Dodatkowo zamieszczane są recenzje i omówienia książek o tematyce archiwalnej.

Popołudniową część sesji rozpoczął wykładem „Archiva Ecclesiastica” - organ Stowarzyszenia Archiwistów Kościelnych, ks. dr hab. Paweł Wolnicki ze Stowarzyszenia Archiwistów Kościelnych. Autor przedstawił historię powołania w 2004 r. Stowarzyszenia Archiwistów Kościelnych, które skupia archiwariuszy instytucji kościelnych. Prelegent opisał również założenia programowe pisma Archiva Ecclesiastica, którego pierwszy numer ukazał się w 2004 r. Rocznik ma charakter regularnego biuletynu i jest forum kontaktowym pracowników archiwów kościelnych. Autor przedstawił skład redakcyjny biuletynu, omówił strukturę pisma oraz najważniejsze artykuły, które ukazały się na łamach periodyku. 
Kolejnym prelegentem był mgr lic. Marek Górniak z Instytutu Leksykograficznego KUL, którego wystąpienie miało tytuł Przeglad powojennych czasopism kościelno-religijnych Dolnego Ślaska i Ziemi Lubuskiej w zbiorach Biblioteki Uniwersyteckiej KUL. Autor rozpoczynając swoje wystąpienie przypomniał, że Biblioteka Uniwersytecka KUL posiada największy zbiór czasopism kościelnych w Polsce. M. Górniak skupił się na pismach diecezji zielonogórsko-gorzowskiej, archidiecezji wrocławskiej, diecezji legnickiej i diecezji świdnickiej. Przypomniał, że do 1989 r. kościelny ruch wydawniczy był ograniczony, zwłaszcza w latach 1945-1955. Ukazywały się wtedy zasadniczo pojedyncze książki, zarządzenia kościelne, ulotki, biuletyny wydawane przez kurie i rozprowadzane wśród duchowieństwa, do użytku wewnętrznego. Aktualnie czasopisma naukowe wydawane są niemal w każdej diecezji. Zawierają one różnorodne artykuły z teologii, katechetyki, historii, informacje z działalności diecezji czy też dział recenzyjny.

M. Górniak pokrótce przedstawił pisma diecezji zielonogórsko-gorzowskiej: „Zarządzenia Administracji Apostolskiej”, „Zarządzenia Kurii Gorzowskiej” (1951-1952), „Gorzowskie Wiadomości Kościelne” (1957-1991), „Ecclesiastica”, „Studia Paradyskie” oraz „Kotwicę Nadziei” (aktualnie: „Kotwica”).

Archidiecezję wrocławską reprezentują: „Wiadomości Kościelne”, „Wrocławskie Wiadomości Kościelne”, „Wrocławskie Studia Teologiczne”, „Dolnośląskie Pismo Katolickie”, „Boży Siewca” (z parafii w Oleśnicy), „Wrocławski Przegląd Teologiczny" (wydawany przez Papieski Wydział Teologiczny we Wrocławiu), „Vox Nostra” (pismo alumnów Wyższego Seminarium Duchownego we Wrocławiu). W diecezji legnickiej wydawano m.in. „Legnickie Wiadomości Diecezjalne” oraz „Perspectiva”. Piśmiennictwo diecezji świdniciej reprezentowane jest przez: „Świdnickie Wiadomości Kościelne”, „Swidnickie Studia Teologiczne”, ,Zeszyty Naukowe WSD Braci Mniejszych w Kłodzku”, „Głos św. Franciszka”, „Życie Konsekrowane” - misjonarzy klaretynow.

Dr Beata Skrzydlewska z Lublin przedstawiła Stan badań nad muzealnictwem kościelnym w Polsce w Ośrodku Archiwów Bibliotek i Muzeów Kościelnych. Prelegentka zaznajomiła zebranych z historią muzealnictwa kościelnego na ziemiach polskich. Pierwsze muzeum kościelne powstało w 1870 r. we Włocławku. Głównymi celami jakie sobie stawiały te instytucje kultury było gromadzenie zbiorów i zabezpieczenie ich przed zniszczeniem. Oprócz eksponatów o proweniencji kościelnej przechowywały też pamiątki narodowe.

Przez długie lata brakowało w Polsce specjalistycznego periodyku, zajmującego się muzealnictwem kościelnym. Sytuacja zmieniła się wraz z powstaniem w 1956 r. Ośrodka Archiwów Bibliotek i Muzeów Kościelnych. Organem wydawniczym ośrodka jest półrocznik „Archiwa Biblioteki i Muzea Kościelne”, którego pierwszy numer ukazał się w 1959 r. Na jego łamach ukazują się różne artykuły z muzealnictwa. Zazwyczaj są to teksty informujące o zbiorach kościelnych, monografie muzeów kościelnych (diecezjalnych, parafialnych), instrukcje opracowywania zbiorów, inwentarze i katalogi muzealne, prawodawstwo kościelne dotyczące dóbr kultury, muzealnictwa kościelnego oraz informacje z życia muzeów. Ukazują się również recenzje publikacji dotyczących muzeów i muzealnictwa kościelnego. Drukowane są też artykuły dotyczące sztuk plastycznych, często nie 
będących własnością Kościoła katolickiego (szaty liturgiczne, obrazy). Na koniec prelegentka przypomniała, że w ramach serii wydawniczej Biblioteka Ośrodka Archiwów Bibliotek i Muzeów Kościelnych ukazała się pozycja Muzea Kościoła katolickiego $w$ Polsce. Informator.

Ks. dr hab. Mieczysław Różański z Uniwersytetu Warmińsko-Mazurskiego w Olsztynie zaprezentował tekst: Prace i Materiaty Historyczne Archiwum Archidiecezji w Łodzi i Muzeum Archidiecezjalnego Łódzkiego. Prelegent opisał statut muzeum i archiwum diecezjalnego w Łodzi, które to instytucje stanowią jeden organizację. Przedstawił również sylwetkę ks. Henryka Rybusa, dyrektora muzeum i archiwum diecezji łódzkiej. W 1939 r. rozpoczął on wydawanie pisma „Prace i materiały historyczne archiwum diecezjalnego w Łodzi”. Było to jedyne czasopismo naukowe w II RP wydawane przez archiwum diecezjalne. Na jego łamach opisywano zasób archiwów parafialnych, bibliotek kościelnych czy też wyodrębnionych zbiorów. Rozwój pisma przerwał wybuch II wojny światowej.

Reaktywacji pisma dokonali w 2005 r. ks. Jerzy Spychała, dyrektor Muzeum Archidiecezji w Łodzi oraz ks. Kazimierz Dąbrowski, dyrektor Archiwum Archidiecezjalnego Łódzkiego. Zachowano ciągłość wydawniczą. Tytuł, ze względu na przemiany organizacyjne zmodyfikowano na: „Prace i Materiały Historyczne Archiwum Archidiecezji w Łodzi i Muzeum Archidiecezjalnego Łódzkiego". Corocznie ukazuje się jeden tom z artykułami z dziedziny muzealnej, archiwalnej, historii i historii sztuki. Na łamach pisma publikowane są m.in. inwentarze zasobu Archiwum Archidiecezjalnego w Łódzi (katalogi metrykaliów, mikrofilmów, rękopisów i starodruków), artykuły dotyczące konserwacji dzieł sztuki, sprawozdania z działalności archidiecezjalnego archiwum i muzeum, referaty z sesji naukowych oraz opracowania historyczne o charakterze regionalnym.

Następny prelegent, ks. dr Marian Brudzisz CSsR, przedstawił referat: Co wniesie do wiedzy historycznej zawartość Archiwum Polskiej Misji Katolickiej we Francji? Ks. M. Brudzisz, wieloletni archiwista w wielu parafiach polskich we Francji, przedstawił historię założonej w 1922 r. Polskiej Misji Katolickiej w La Fèrte k. Paryża. Archiwum misji od kilku lat jest porządkowane przez prelegenta. Posiada ono 36 zespołów, niektóre o charakterze szczątkowym. Największy zespół obejmuje akta PMK (działalność PMK we Francji, władze, relacje z hierarchią kościelną, duszpasterze, akta osobowe, ośrodki duszpasterskie, biuletyny parafialne, duszpasterstwo obozów dla Polaków i kompanii wartowniczych, akcje dobroczynne 1939-1945 r., organizacje społeczne np. Polski Związek Inwalidów we Francji, Zjednoczenie Polskiego Uchodźctwa we Francji, Związek Harcerstwa Polskiego, listy Francuzów do Prymasa Polski w czasie stanu wojennego, kierowane do rektora.

Kolejny referat, Pierwsze polskie czasopismo teologiczne o charakterze naukowym „Przyjaciel Chrześcijańskiej Prawdy” 1833-1840, wygłosił ks. dr Sławomir Zych z Ośrodka Badań nad Polonią i Duszpasterstwem Polonijnym KUL. Wspomniane pismo powstało w Przemyślu, stolicy dwóch diecezji katolickich: obrządku łacińskiego i wschodniego. Twórcą pisma był ks. Michał Korczyński (1784-1839), kanonik kapituły przemyskiej, późniejszy biskup przemyski obrządku łacińskiego (1834-1849). Kwartalnik „Przyjaciel Chrześcijańskiej Prawdy” 
ukazywał się od 1833 r. i był pismem teologicznym o charakterze naukowym. $\mathrm{Na}$ jego łamach ukazywały się artykuły z dogmatyki, teologii moralnej, pastoralnej, edycje dokumentów ze zbiorów kapituły i katedry przemyskiej (uposażenie kapituły, biskupstwa, dokumenty fundacyjne, dzieje większych parafii), nekrologi zasłużonych osób, żywoty świętych. Nakład pisma wynosił poczatkowo 100 egzemplarzy, by w 1840 r. wzrosnąć do 400 egz. Po śmierci bpa M. Korczyńskiego zawieszono wydawanie pisma. Pewną kontynuacją kwartalnika są: „Kronika (Archi)diecezji Przemyskiej obrządku łacińskiego" (od 1901 r.) - założone przez bpa Józefa S. Pelczara oraz ukazujące się od 1987 r. nieregularnie - „Premislia Christiana", pod redakcją ks. Tadeusz Śliwy.

Ostatni referat wygłosił ks. dr Józef Szymański z Włocławka na temat: Polonijna prasa $w$ stużbie wychodźstwa polskiego w okresie międzywojennym na przykładzie Francji. Prelegent przypomniał, że przed II wojną światową na terenie Francji mieszkało ponad 700000 Polaków. Srodowisko emigracyjne wydawało wówczas około 180 tytułów prasowych. Wszystkie większe skupiska polonijne posiadały swoje organizacje, które skupiały się wokół Kościoła katolickiego (kółka śpiewacze, orkiestry, kółka różańcowe, sokolstwo, prasa). Łącznie funkcjonowało w tym czasie ok. 2000 organizacji polskich.

Pisma emigracyjne miały wielki wpływ na robotników ponieważ umacniały polskość oraz wskazywały na najważniejsze problemy Ojczyzny. Służby konsularne II RP, zauważały jednak, że ośrodki wydawnicze stanowią problem dla władz polskich, nie spełniając pewnych idei i zadań. Władze monitorowały stan polskich misji katolickich, sugerując często Prymasowi Polski decyzje personalne. Duchowni, którzy zbyt mocno angażowali się w swoją pracę społeczno-narodową na łamach pism polonijnych byli odwoływani na skutek decyzji władz polskich, ale często i francuskich, które dążyły do jak najszybszej asymilacji Polaków we Francji. 